\title{
Application of $\alpha$-lipoic acid beyond peripheral diabetic polyneuropathy (A report of 3 cases)
}

\author{
Hans-Joachim Freisleben, ${ }^{1}$ David Tandian, ${ }^{2}$ Krista Kuebel-Thiel ${ }^{3}$ \\ ${ }^{1}$ Faculty of Medicine Universitas Indonesia, Jakarta, Indonesia \\ ${ }^{2}$ RSUPN Dr. Cipto Mangukusumo, Neurosurgery Department, Jakarta, Indonesia \\ ${ }^{3}$ Private Practice, Egelsbacher Str. 20, 64390 Erzhausen, Germany
}

\begin{abstract}
Abstrak
Latar belakang: Di Jerman, asam lipoid terdaftar dengan indikasi "polineuropati perifer diabetik”. Laporan kasus ini bermaksud mempertunjukkan aktivitas terapetik yang melebihi indikasi ini. Di Indonesia, substansi ini tidak terdaftar untuk terapi.

Metoda: Tiga pasien (dua di antaranya di Jerman, dan satu di Indonesia) dengan gejala patologi neurologikyang berbeda dari polineuropati diabetik perifer diterapi dengan asam $\alpha$-lipoat: i) gejala peradangan pasca-boreliosis dengan artritis dan parestesi, ii) gangguan sensorik dan motorik pasca kemoterapi dan pasca operasi karsinoma mammae yang terjadi sejajar dengan terapi radiasi, dan iii) krisis pulmonar dan kardiovaskular pasca-trauma dan pasca bedah otak, dengan gangguan patologi neurologik (sensorik, motorik, visual dan auditorik) serta disartria.

Hasil: Ketiga pasien mengalami perbaikan begitu dimulai dan dilanjutkan pemberian asam lipoat, sementara tindakan terapetik lainnya tampaknya kurang memberi hasil baik. Kemungkinan terjadinya interaksi antara terapi lain dengan asam lipoat, kemungkinan secara sinergistik atau aditif pendukung, tidak dapat disingkirkan; namun, secara terpisah, atau dengan interaksi, tampaknya asam lipoat membantu kesembuhan pada pasien-pasien tersebut dari gejala patologi neurologik, dalam istilah kedokteran tradisional "restitutio ad integrum".
\end{abstract}

Kesimpulan: Pada ketiga kasus pada penelitian ini, asam lipoat agaknya efektif untuk keadaan patologi neurologik yang berbeda dari neuropati diabetik perifer. Diperlukan studi selanjutnya untuk memastikan efektivitas ini. (Med J Indones 2011; 20:143-8)

\begin{abstract}
Background: In Germany, lipoic acid is registered with the indication of "peripheral diabetic polyneuropathy". This report intends to demonstrate therapeutic activity beyond this indication. In Indonesia, the substance is not registered for therapy.

Methods: Three patients (two of them in Germany and one in Indonesia) with pathoneurological symptoms different from peripheral diabetic polyneuropathy were treated with $\alpha$-lipoic acid: i) post-borelliosis inflammation with arthritic and paraesthetic symptoms, ii) post-operative (mamma carcinoma) and post-chemotherapeutic sensoric and motoric neural deficits occurring in parallel with additional radiation therapy, and iii) post-traumatic (cerebral) and postoperative (brain surgery) cardiovascular and pulmonary crisis with broad pathoneurological (sensoric and motoric, visual, auditory) deficits and dysarthria.
\end{abstract}

Results: All three patients improved in close correlation with the onset and continuation of lipoic acid intake, whereas other therapeutic measures did not appear very successful. It cannot be ruled out that the other therapeutic regimens applied interacted with lipoic acid in a supporting additive or synergistic manner, because three cases as reported here do not allow for such conclusion; however, separately, or with interaction, lipoic acid helped the patients to recover from their pathoneurological symptoms in the meaning of the traditional medical term "restitutio ad integrum".

Conclusion: In the three cases in this study, lipoic acid was effective in therapy of pathoneurological symptoms different from peripheral diabetic neuropathy. Further confirmative studies are suggeted. (Med J Indones 2011; 20:143-8)

Key words: $\alpha$-Lipoic acid, cancer therapy, cerebral trauma, infection, inflammation, neuropathy

Lipoic or thioctic acid (lipoate or lipoamide) in its either reduced or oxidized forms, is a physiological cofactor of mitochondrial dehydrogenases. Apart from its physiological role, the compound is of interest in therapeutic aspects under pathological conditions, which latter activities are considered here. Its reduced form, dihydrolipoate (DHL) cannot be used as a drug because it is unstable and rapidly oxidized. However, administration of the oxidized form to the body sufficiently provides dihydrolipoate via enzymatic and non-enzymatic equilibrium mechanisms. ${ }^{1,2}$ In in vitro experiments DHL is the reactive principle, this appears to hold true in vivo also for administration of lipoic acid, because it is physiologically involved in redox cycles and is easily recycled by itself; in biological systems both DHL and lipoic acid act as potent antioxidants. ${ }^{3,4}$

The $\mathrm{pK}$ values of the -SH groups of DHL are high (approximately 10.7). ${ }^{5}$ However, dissociation of the -SH groups does not appear to be a major factor which determines antioxidant activity of thiols. Similar to other vicinal dithiols, DHL is more easily oxidized 
than monothiols. ${ }^{6}$ On the other hand, the tension of the oxidized pentacycle $(3-6 \mathrm{kcal} / \mathrm{mol})$ explains the tendency for reductive splitting due to intra- and extracellular environmental conditions. ${ }^{6}$ The redox potential is very low $(-0.29 \mathrm{Eo} / \mathrm{V}),{ }^{7}$ lower than that of the couple of oxidized/reduced glutathione $(-0.24$ Eo'V), which is reduced by DHL. Hence, lipoic acid stabilizes the major intracellular antioxidant system.

Lipoic acid protects in vivo against the generation of ROS and free radicals in early intestinal reperfusion in rats ${ }^{8}$ and protection of low density lipoproteins by dihydrolipoic acid against the attack of peroxyl radicals was shown ex vivo. ${ }^{9}$ In these experiments, recycling of tocopherol and probucol in LDL by ascorbate was demonstrated, which effect was tremendously prolonged by the addition DHL. ${ }^{10}$ The redox potential of LA/ DHL is also lower than that of the ascorbate redox system, the major extracellular water soluble antioxidant, thus also stabilizing the reduced extracellular status.

Reactive oxygen species (ROS) and peroxyl radicals are intimately involved in ischemia and reperfusion events, generated in the blood but also at a variety of cellular and subcellular sites, especially in the endothelium. Mitochondria may be the main source of oxygen free radicals fromimpaired electron transport and mitochondrial ATPsynthase might primarily be attacked. ${ }^{11}$

The mitochondrion is probably also a site of action ofDHL. The compound is sufficiently hydrophobic to permeate biological membranes at high rates. The lipophilicity of DHL may furthermore be a part of its pharmacological efficacy, not only in terms of pharmacokinetics and distribution, ${ }^{12}$ but also in the site of pharmacodynamic interaction. In the mitochondrial membrane, sensitive thiols of membrane proteins in hydrophobic environment ${ }^{13}$ may be protected by DHL via -SH/-S-S- interchange influencing ATP synthesis and phospho-creatine kinase, i.e., mitochondrial energy turnover. ${ }^{14,15}$ Hence, the cellular damages of ischemia and hypoxia on one side and noncontrolled reperfusion and reoxygenation on the other are diminished by lipoic acid in animal models. ${ }^{16}$ Furthermore, life expectancy of immunosuppressed mice was slightly improved at low doses of lipoic acid. ${ }^{17}$

This report comprises two cases from Germany and one case from Indonesia. In the latter country, lipoic acid is not registered whereas in Germany, the compound is registered with its indication for the treatment of peripheral diabetic polyneuropathy. ${ }^{18}$

However, neuroprotection beyond this indication had been demonstrated in various models and under various conditions. ${ }^{19-22}$ This report shows considerable improvement and therapeutic success with lipoic acid in three cases of pathoneuroligical conditions with different etiological background.

\section{METHODS}

All mentioned medication was obtained from public pharmacies or hospital pharmacies, respectively, in Germany or Indonesia.

The $\alpha$-lipoic acid pro infusionem preparation was purchased from StadaAG, 61118 Bad-Vilbel Dortelweil, Germany, via a public pharmacy (Heegbach-Apotheke, 60430 Erzhausen, Germany) and brought to Indonesia by one of the authors (HJF).

\section{Treatment}

All patients obtained $600 \mathrm{mg}$ of $\alpha$-lipoic acid daily as a single oral dose early in the morning, at least half an hour before breakfast or intake of any other medication.

Patient 3 obtained $600 \mathrm{mg}$ of $\alpha$-lipoic acid per infusionem for three days early in the morning, at least half an hour before breakfast. After three days, medication with lipoic acid was continued orally, as above.

\section{RESULTS}

\section{Lipoic acid in paraesthesia and inflammation after borelliosis (Germany):}

Therapist: Hans-Joachim Freisleben, DMedSc, MPharm, $\mathrm{PhD}$, Biochemical Pharmacologist \& Professor of Biomedicine, Faculty of Medicine Universitas Indonesia, Jl. Salemba No. 6, Jakarta 10430, Indonesia, Tel: +6221-70313998.

Cases 1: Female patient aged 56, presented in October 2008 with swollen and stiff fingers, swollen finger joints accompanied by paraesthesias of the arms and fingers.

Anamnesis: History of toxoplasmosis (1992-93) during extended stays in tropical countries. Toxoplasmosis was treated with daraprime. Long-term existing hypothyreosis recently diagnosed as Hashimoto thyreoditis has been therapied for years with L-thyroxin $125 \mathrm{mg}$. About three months ago, tick-borne borelliosis was treated with doxicycline, afterwards above borelliosis-arthritis symptoms and paraesthesias occurred.

Therapy: Anti-inflammatory enzyme therapy (tablets containing papain, bromelain) was initiated with 9-12 tablets per day over three months with minor improvement of the symptoms. Subsequently, $\alpha$-lipoic acid was applied orally, $600 \mathrm{mg}$ per day, 30 minutes before breakfast and L-thyroxin intake, respectively.

Result: Three months later, fingers had become normally shaped, paraesthesias disappeared and joints were almost free of inflammation. 
Therapy was continued with $300 \mathrm{mg} \alpha$-lipoic acid until joints were totally free of inflammatory symptoms. In addition, selenium-vitamin $\mathrm{E}$ supplementation was applied to support L-thyroxin therapy for Hashimoto thyreoditis. After another two months (in spring 2009), $\alpha$-lipoic acid therapy and selenium-vitamin E supplementation were discontinued.

No inflammatory symptoms re-occurred during summer and autumn 2009. In very cold winter days 2009/2010 (outside temperatures below $-15^{\circ} \mathrm{C}$, patient needs to walk her dog), slight swelling of finger joints and stiffness of the fingers was observed and follow-up therapy with $600 / 300 \mathrm{mg} \alpha$-lipoic acid as above was successfully advised.

\section{Lipoic acid in paraesthetic and motoric disorders after breast cancer therapy (Germany):}

Therapist: Krista Kuebel-Thiel, MPharm, Natural Practitioner (Diploma), Egelsbacher Str. 20, 64390 Erzhausen, Germany, Tel.: +49-6150-83399

Cases 2: Female aged 57 presented in February 2008 with loss of motoric in upper and lower extremities, patient reported about insensitivity in hands and feet, no feeling of hot and cold or pain and complained about difficulties with climbing and descending stairs and to fall down frequently.

Anamnesis: History with breast cancer left, first diagnosed in June 2006 as bifocal invasive ductal mamma carcinoma, receptor (ER, PR, Her2new) negative.

Surgical treatment, operation 14-06-2006: tumour resection and fibroadenom excision left, Sentinel lymph node (SLN) biopsy and subsequent axilla dissection left (2 SLNs resected, 1 metastasis positive); operation without complications, resection status R0.

Postoperative status: mamma and 18 lymph nodes left tumour free; in thorax, bones, liver, genitals no metastases detected. Laboratory values normal except for increased leukocytes.

Postoperative therapy: 4 cycles of chemotherapy (adriamycin=doxorubicin/cyclo-phosphamide/ paclitaxel) and subsequent radiotherapy between Dec. 06 and Febr. 07 (50.4 Gy at 5x1.8 Gy/week increasing to $66.4 \mathrm{~Gy}$ at max. $5 \times 2 \mathrm{~Gy} /$ week).

Because of diagnosed osteopeny calcium and vit. D supplementation was advised.

From the beginning of chemotherapy in 2006 patient complained about loss of mobility function in her feet when walking and especially stepping stairs. Hands and feet became insensitive with subsequent loss of motoric function and of feeling for cold and hot, sharp or dull pain. Patient complained to fall down frequently and not to be able to move her toes any more.

Patient reports that soon after, sensitivity got totally lost in front part of her feet and that she could no longer use her hands properly, e.g., she failed to grasp and hold objects.

In neurological examination, patient presented with neurological deficits both sensoric (paraesthetic, e.g., patient could not differentiate between single toes) and motoric (atactic, paraplegic).

Starting from March 2008, $\alpha$-lipoic acid $600 \mathrm{mg}$ was taken daily except Sundays, accompanied by physio-therapy of the feet, "chiro antipolyneuropathy treatment".

Result: After 4 weeks sensitivity returned to the feet, motoricity normalised in her hands and feet, walking facility improved week by week as hands and feet could be used properly, after 8 weeks patient could step stairs.

Status July 2008: all motoric and neurologic functions normal, patient reports about slight and paroxysmal paraesthesia of her toes, no other complaints.

\section{Lipoic acid in traumatic brain injury and postoperative recovery (Indonesia):}

Therapist: David Tandian, MD, Neurosurgeon, on duty 07-06-2006, at Neurosurgery Unit Hospital: Rumah Sakit Pusat Pertamina (RSPP), Jl. Kyai Maja no.43 Kebayoran Baru, Jakarta Selatan 12120, Indonesia Tel: +62-21-720-0290; Fax: +62-21-720-3540.

Cases 3: male patient aged 72, rushed to Emergency Unit of RSPP Hospital by police car after traffic accident on 07-06-2006 at 6:00 p.m.

Anamnesis: traffic accident, patient hit by motor cycle 30-45 min ago, patient's head was injured with bleeding from his nose; patient was unconscious at arrival, therefore cerebral disorientation and previous vomiting remained unclear.

Diagnosis: General condition stable BP: $147 / 85 \mathrm{mmHg}$; HB $108 / \mathrm{min}$; $\mathrm{BT}$ : $35,9^{\circ} \mathrm{C}$; brain injury with nose bleeding; mid-sternal scar from thorax operation (history of cardiac surgery 1999), residual appearance normal;

Tentative diagnosis: inner bleeding / cerebral haematoma;

Neurological examination: Patient in conscious condition (compos mentis), mild to moderate somnolence $(\mathrm{GCS}=12)$; indication to conduct brain surgery was further decline of consciousness during examination.

Cerebral CT (07-06-06): acute subdural dextral frontotemporoparietal haematoma, contusio cerebri at basis and midline shift to the left $>0.5 \mathrm{~cm}$. 
Neurosurgery, operation 07-06-2006, intra-operative findings: depressed fracture of the dextral communitive frontotemporal bone; epidural haematoma, $10 \mathrm{ml}$; lacerations of duramater and cerebrum, $3 \mathrm{~cm}$; subdural haematoma, $50 \mathrm{ml}$, with source of bleeding from dextral fissura sylvii vene.

Postoperative status: 6 days ICU; Blood pressure stabilized and consciousness recovered during the first post-operative day; however, strong headaches and impaired sensorial, auditory, visual and motoric functions as well as dysarthria remained; THT consultation clarified that audition deficit did not seem due to impaired auditory area but was more likely caused by a blood clot in the external auditory meatus. CT scan (16-06-06) revealed no more bleeding and no midline shift.

Complications during hospitalization: Two severe postoperative cardiovascular and pulmonary crises occurred within two weeks; pneumonia was diagnosed on 14-06-06 (laboratory: CRP $118 \mathrm{mg} / \mathrm{L}$; sputum: Strept. pneumoniae, Staph. epidermidis, Cand. tropicalis), which pneumonia (possibly HAP-VAP and with a predisposition factor to COPD) caused long-term hospitalization until improvement could be stated on 1807-06.

Cerebral MRI (23-06-06): slight subacute-chronic intracerebral haematoma temporal right and subdural haematoma frontal-parietal-temporal-occipital bilateral; prominent old infarct centre bilateral, at pons / brain stem right and temporal left; chronic bilateral otomastoiditis and sphenoidal haematosinusitis.

Thorax: Cardiomegaly with aortic elongation, dilation and calcification, pleural effusion left, bronchopneumonia.

Cerebral CT (07-07-06): slight cerebro-cerebellar atrophy, ventricle dilation

\section{Special treatment during hospitalization / postoprative pharmacotherapy:}

albumine, sertraline $\mathrm{HCl}$, sulbutiamine, carbazochrom Na-sulfonate, piracetam, methylprednisolone, ketorolac tromethamin, citicholin, dobutamin $\mathrm{HCl}$, nimodipine, theophylline/aminophylline, tranexamate acid, erdosteine; antibiotic therapy against upcoming bronchopulmonary and eye/ear infections: cefotaxim $\mathrm{Na}$, fosfomycin $\mathrm{Na}$, cefoperazon $\mathrm{Na}$, cefixim, fluconazole; eye drops: levofloxacine; ear drops: fludrocortisone acetate/ polymyxine-B-sulfate/neomycine sulfate/lidocaine $\mathrm{HCl}$. In addition the patient obtained up to 9 inhalations per day with tiotropium or ipratropium bromide, salbutamol and budesonide.

The patient was supplemented with 'enzyplex' (amylase/ protease/lipase/vit.B-complex), neuro-vit.B-complex, fish oil, natural vit.E, vit.C, vit.K, mecobalamine; and
- if necessary - obtained Mg-/Al-hydroxide/simeticon, ranitidine $\mathrm{HCl}$, lactulose.

\section{Continuous pharmacotherapy:}

Morning: carbamazepine, isosorbid dinitrate, tegaserod, $\mathrm{N}$-acetylcysteine, spironolactone, eperisone $\mathrm{HCl}$, tolterodine 1-tartrate;

Noon time: eperisone $\mathrm{HCl}$;

Evening: carbamazepine, isosorbid dinitrate, tegaserod, eperisone $\mathrm{HCl}$;

Before sleeping: tolterodine 1-tartrate, simvastatin;

Rehabilitation physiotherapy was applied without significant improvement of the general and neurological condition.

Two weeks after brain surgery and after two subsequent severe and life-threatening crises, three infusions of a-lipoic acid $600 \mathrm{mg}$ daily were given on three consecutive days (days $1-3$ ), early in the morning. Subsequently (from day four), $600 \mathrm{mg}$ daily were administered per os, early in the morning half hour before breakfast. Daily pharmacotherapy (see above) was continued.

After 59 days patient was released from hospital on 23-072006 , a-lipoic acid therapy was continued for another 50 days and accompanied by natural multivitamin supplementation. The entire a-lipoic acid therapy was $600 \mathrm{mg}$ per day for 103 days, three days intravenously, 100 days orally.

Result: about one month after the patient had been released from hospital he could move freely without any walking aid, he had full recovery of all neural functions, sensoric and motoric, central and peripheral. Patient continued with controlled therapeutic sports activities until date.<smiles>O=C(O)CCCCC(S)CCS</smiles>

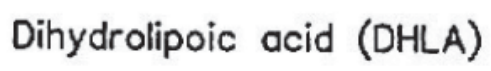<smiles>O=C(O)CCCCC1CCSS1</smiles>

$\alpha$-Lipoic acid (LA)

Figure 1. Chemical structures of dihydrolipoic acid and $\alpha$-lipoic acid 


\section{DISCUSSION}

All three patients presented with neural impairment different from the approved indication for $\alpha$-lipoic acid of peripheral diabetic polyneuropathy. The first patient had post-borelliosis-infection arthritic and pathoneurologcal symptoms, the second patient postchemotherapy pathoneurological symptoms, and the third patient post-brain-trauma with cerebral hematoma and post-operative generalized neurological deficits. Hence, aetiology and history of these patients were very diverse. Furthermore, medication was diverse as well:

Let's look into the single cases more detailed, the first case of longterm inflammation after borelliosis infection developed oxidative stress with oxygen free radical formation due to inflammation. Initial therapy with anti-inflammatory enzymes bromelaine and papaine was not satisfactory, so it was decided to use the potent antioxidant lipoic acid. The supplementation with selen-vit E is likely to benefit from lipoic acid too because the latter had been shown to expand the lifetime of vit E, which was interpreted as "recycling" of vit E-radical to the reduced form of vit E. ${ }^{9,10}$ Lipoic acid obviously cured the inflammatory processes which led to the arthtritic and paraesthetic symptoms.

In the second patient we focus on the onset of pathoneurological symptoms with chemotherapy in order to interpret the toxic side effects of chemotherapy, althoughalso in this case oxidative stress and inflammation because of the patient's history with cancer, surgery and radiation certainly play an important role as well. But in this case the capability of lipoic acid to restore enzymes and other proteins prevails through interaction with the -SH regeneration and -SH / -S-S- exchange systems including those of glutathione, thioredoxin and disulfide isomerases.

The third case is certainly the most complex condition both from the etiological background, brain surgery and pharmaco-medication. After the very complex cerebral traumaand brain surgery with excellentsurgical outcome, the patient still suffered considerable pathoneuroligical deficits. Acute bronchitis and pulmonary infection (pneumonia, pleurisy), which could have been acquired through hospitalization (HAP-VAP) caused general weakness and blood circulation instability on the background of the patient's cardiovascular history with post-infarction thorax surgery (about 7 years ago) and led to long-term hospitalization.

The situation made multifold medication necessary with a wide arsenal of cardiovascular and antibiotic pharmaceuticals. In addition, nootrophyl for the post-traumatic improvement of the nervous system were administered such as piracetam. Finally and successively, vitamins were applied and PUFAs from fish oil as supplementation.

Two severe and life-threatening events supported the decision to give 3 infusions with lipoic acid and to continue this therapy with $600 \mathrm{mg}$ daily per os. From the medication and supplementation of this patient it cannot be stated that it was solely lipoic acid that improved his condition as constantly as it was observed in parallel with the intake of this compound. A wide field of interactions may apply to this situation. However, posttraumatic reperfusion is known to cause tremendous oxidative stress, which can be reduced by lipoic acid more effectively than by other antioxidants, ${ }^{21,22}$ which is in parts due to its easy distribution into central and peripheral nerves. Furthermore, for recovery of the nerves improvement of mitochondrial functions and energy metabolism are crucial. As a co-factor of mitochondrial dehydrogenases lipoic acid would certainly improve oxidative phosphorylation and thus supply with ATP.

In two cases, physiotherapy was applied and in one case, there was no physiotherapy. In the former two cases, physiotherapy was not considered very effective, so we interpret that it was not primarily physiotherapy the brought back neurological functions but lipoic acid therapy since the course of recovery closely followed the onset and continuation of its intake.

In conclusion, in the three cases in this study lipoic acid was effective in the treatment of pathoneurological symptoms beyond peripheral diabetic polyneuropathy.

\section{Acknowledgments}

From year 1988 until 1993, project funding was provided by Asta Medica AG, Frankfurt am Main, Germany, to the Laboratory of H.-J. Freisleben, Centre of Biological Chemistry, Faculty of Medicine, J.W. Goethe-University Frankfurt am Main, Germany, in order to support studies on lipoic acid.

\section{REFERENCES}

1. Suzuki YJ, Tsuchiya M, Packer L. Thioctic acid and dehydrolipoic acid are novel antioxidants which interact with reactive oxygen species. Free Rad Res Commun. 1991;15:255-63.

2. Han D, Handelman GJ, Packer L. Analysis of reduced and oxidized lipoic acid in biological samples by highperformance liquid chromatography. Methods Enzymol. 1995; 251:315-25.

3. Handelman GJ, Han D, Tritschler H, Packer L. a-Lipoic acid reduction by mammalian cells to the dithiol form, and released into the culture medium. Biochem Pharmacol. 1994;47:1725-30. 
4. Haramaki N, Handelman GJ. Tissue-specific pathways of a-lipoic acid reduction in mammalian systems. In: Fuchs J, Packer L, Zimmer G, editors. Lipoic Acid in Health and Disease. NewYork: M Dekker, Inc.; 1997. p. 145-62.

5. Gascoigne IM, Radda GK. The chemistry of flavins and flavoproteins. III. The reaction of dihydrolipoic acid with flavins. Biochim Biophys Acta. 1967;131:498-507.

6. Jocelyn PC. Biochemistry of the -SH group. London, New York: Academic Press; 1972.

7. Searls RL, Sanadi DR. a-Ketoglutarate dehydrogenase. VIII. Isolation and some properties of a flavoprotein component. J Biol Chem. 1980;235:2485-91.

8. Roldan EJ, Kerzberg EM, Boveris A. Kinetics of chemoluminescence of rat intestine during ischemia and reperfusion. Medicina (Buenos Aires) 1989;49:336-40.

9. Freisleben HJ, Kagan VE, Packer L. Recycling of antioxidants in LDL. A novel approach to antiatherogenesis. In: Book of Abstracts of the $1^{\text {st }}$ International Conference of Pathophysiology (ISP/SFFR) Moscow: 1991. p. 228-9.

10. Kagan VE, Freisleben HJ, Tsuchia M, Forte T, Packer L. Generation of probucol radicals and their reduction by ascorbate and dihydrolipoic acid in human low density lipoproteins. Free Rad Res Comm. 1991;15:265-76.

11. Hyslop PA, Hinshaw DR, Halsey WA Jr, Schraufstätter IV, Sauerheber RD, Spragg RG et al. Mechanisms of oxidantmediated cell injury. The glycolytic and mitochondrial pathways of ADP phosphorylation are major intracellular targets inactivated by hydrogen peroxide. J Biol Chem. 1988;263:1665-75.

12. Hermann R, Niebch G. Human pharmacokinetics of a-lipoic acid. In: Fuchs J, Packer L, Zimmer G, editors. Lipoic Acid in Health and Disease. New York: M Dekker, Inc. 1997. p.337-60.

13. Freisleben HJ, Fuchs J, Mainka L, Zimmer G. Reactivity of mitochondrial sulfhydryl groups towards dithionitrobenzoic acid and bromobimanes under oligomycin-inhibited and uncoupling conditions. Arch Biochem Biophys. 1988;266: 89-97.

14. Bittl JA, Ingwall JS. Reaction rates of creatine kinase and ATP synthesis in the isolated rat heart. A ${ }^{31} \mathrm{P}$ NMR magnetization transfer study. J Biol Chem. 1985;260: 3512-17.

15. Freisleben $\mathrm{HJ}$, Zimmer G. Mitochondrial $\mathrm{F}_{1} \mathrm{~F}_{0}$ ATPase in hypoxia. Comparison of two differently isolated complexes in presence of dihydrolipoic acid. In: Benzi G, editor. Advances in Myochemistry Vol.2. London, Paris: J. Libbey Ltd; 1989. p.51-2.

16. Freisleben HJ. Lipoic acid reduces ischemia-reperfusion injury in animal models. Toxicology. 2000;148:159-71.

17. Freisleben HJ, Neeb A, Lehr F, Ackermann H. Influence of selegiline and lipoic acid on the life expectancy of immunosuppressed mice. Arzneim Forsch/Drug Res. 1997;47(I):776-80.

18. Haak E, Usadel KH, Kusterer K, Amini P, Frommeyer R, Tritschler HJ, Haak T. Effects of alpha-lipoic acid on microcirculation in patients with peripheral diabetic polyneuropathy. Experimental and Clinical Endocrinology and Diabetes. 2000;108: 168-74.

19. Krieglstein J, Peruche B, Prehn J, Nuglisch J, Karkoutly C. The neuroprotective effect of dihydrolipoic acid. In: Schmidt K, Ulrich H, editors. $2^{\text {nd }}$ International Thioctic Acid - Workshop: The Role of the Redox System AlphaLipoic Acid / Dihydrolipoic Acid in Organ-Specific Models of Impaired Oxygen Supply. Frankfurt/Main: UniversimedVerlag. ISBN 3-89143-018-3. 1992. p.89-102.

20. Wolz P, Krieglstein J. Neuroprotective activity of lipoic and dihydro-lipoic acid. In: Fuchs J, Packer L, Zimmer G, editors. Lipoic Acid in Health and Disease. New York: M Dekker, Inc; 1997. p.205-25.

21. Packer L, Tritschler HJ, Wessel K. Neuroprotection by the metabolic antioxidant $\alpha$-lipoic acid. Free Radic. Biol. Med. 1997;22:359-78.

22. N, T. (2017). Mau nanya dong dok. [online] Mau nanya dong dok. Available at: https://nanyadongdok.blogspot.com [Accessed 2 Jul. 2017]. 